\title{
Is the Stock Market Overvalued: A Study in the Context of Bangladesh?
}

\author{
Mohammad Nayeem Abdullah', Kamruddin Parvez ${ }^{2}$, Moslehuddin Khaled $^{3}$
}

${ }^{1}$ School of Business, Independent University, Chittagong, Bangladesh

${ }^{2}$ School of Business, Independent University, Chittagong, Bangladesh

${ }^{3}$ School of Business, Independent University, Chittagong, Bangladesh

\begin{abstract}
The primary objective of this paper is to analyze if the Market overvalued. We studied prices of 17 actively companies in the Market from 2006 to 2010 and used three Valuation Ratios with an explicit corporate sector along with overall market index data and found that the Stock Marke overvalued. The analysis was completed in two stages. At first we analyzed each of the 17 companies to determine the condition of each company. This part shows that among 17 companies most of the companies' share prices are overvalued and they are also inefficient in managing costs. The second stage of the analysis is composed of 17 companies share prices along with examination of capital accumulation in corresponding period. This result also shows that the market overvalued. From my analysis a relationship has been found between mass capital accumulation and Market Overvalued.
\end{abstract}

Keywords: Market, Bangladesh, overvalued, intrinsic value, price -ratio model. JEL Classification Code: E44; E52

\section{INTRODUCTION}

$\mathrm{O}$ UR interest of writing this article originated from the market crash of 2011 and the relevant context of the subsequent events of market in Bangladesh. There are two stock exchanges in Bangladesh: 'Dhaka Stock Exchange' and 'Chittagong Stock Exchange'. In 1996, there was a similar crash in the market. After that market was dull for a few years but gradually gained the momentum with occasional downturn but with no major day crash. In previous years to 2011, stock price increased at a level which seemed unsustainable. Already, many common people - salaried men, housewives, jobless people, small businessmen, students - all poured in their savings into market. Then the time came in November, 2011. Stock price plummeted fast each day and valuation of the stocks decreased by more than $100 \%$. People started agitating on the street, thrashing the vehicles, burning the effigies of the finance minister, SEC(securities and exchange) commission Chairman, and Bangladesh Bank governor, not exactly knowing where to turn for answer.

But who will answer this market paradox? Market prices are open to all and open to competition. Day to day visibility of price movement is higher than any other commodity. Then who to blame! Government is just the one easy to blame.

Market optimism is touted with an indicator of good economy. When market was rising, people saw their fortune is growing every day, government was happily claiming it to be a sign of confidence on the economy. But now back to the basic, people are responsible for their own buy-sell decisions. After that government has been trying hard to provide ad hoc emergency policy support to im- prove the situation or at least prevent further deterioration.

In this context, we observed market correction was long overdue and at what level price stabilized. Whatever level it is, our curiosity is: at that level, is the market corrected? Market correction refers to a general tendency toward equilibrium. So we want to check whether market level is overvalued undervalued according to the established theoretical models.

If it is now undervalued, government need not provide ad hoc non competitive support any more, government should devise long term policy to strengthen the market.

If it is still overvalued, government should tacitly allow the market to correct for some time for the sake of long term health of the market.

\section{INTRODUCTION}

Bangladesh Market has been the subject significant changes in recent years. DSE has also taken significant steps towards the development of its capital market. The market is one of the most important sources for companies to raise money. This allows businesses to be publicly traded, or raise additional capital for expansion by selling shares of ownership of the company in a public market. The liquidity that an exchange provides affords investors the ability to quickly and easily sell securities. This is an attractive feature of investing in stocks, compared to other less liquid investments. History has shown that the price of shares and other assets is an important part of the dynamics of economic activity, and can influence or be an 
indicator of social mood. Rising share prices, for instance, tend to be associated with increased business investment and vice versa. Measures have been taken for privatization, economic liberalization, relaxation of foreign exchange controls, and easing of regulations on repatriation of profits, investment, and operation of financial institutions (Ghazi and Khoda, 2009).

There are two Markets in Bangladesh-Dhaka Stock Exchange and Chittagong Stock Exchange. The Dhaka Stock Exchange (DSE) was first incorporated as the East Pakistan Stock Exchange Association Limited on April 28, 1954. It was renamed as Dhaka Stock Exchange (DSE) Limited on June 23, 1962.After liberation when Dhaka Stock Exchange resumed trading activities in 1976, only 9 companies were listed having a paid up capital of Taka 137.52 million on the stock exchange. By the end of 2005 number of Securities listed on DSE became 260 with market capital of Taka $228,574.85$ million. At present, there are 297 companies are enlisted in

DSE (http://www.dsebd.org/company\%20listing.php) that covers 18 industries (Bank, Cement, Ceramics Sector, Corporate Bond, Debenture, Engineering, Food \& Allied, Fuel \& Power, Insurance, Investment, IT Sector, Jute, Miscellaneous, Paper \& Printing, Pharmaceuticals \& Chemicals, Services\& Real Estate, Tannery Industries and Textile.

Asset price bubble is an economic phenomenon in which values in a particular sector become inflated for a short period of time. If the bubble burst, prices in that sector fall (Chapman, 2007; Knight 2002). Yet, this is hard to predict when this will happen (Black 2002).A description of Market bubble is seemed to be more useful in Kindleberg (1987) which positive feedback and price increases greater than justified by Market fundamentals. A market is an economic bubble which occurs when Market participants drive stock prices above their value in relation to some system of stock valuation(see Figure-3).A bubble occurs when speculators note first rise in the stock value and decide by in expectation of further rises rather than because shares are undervalued. Numerous factors have been responsible for the formation and collapse of stock bubbles from early times. One is the availability of easy credit approval and fungible investments funds that are invested in the market for buying company shares (Craven and Islam, 2008). Intermediary effects imply things one the one hand, there are interlinks consecutive or successive bubbles (Allen and Gale 2002) and also some mediatory dynamics cause to shape the bubbles on the other (Craven and Islam 2008).Intuitively. These interlinks can be interpreted as an existence of a long memory or long dependency of intermediate factors and stock bubbles (Ashraf and Rodriguez, 2006). There were also flows of information between London and Paris and other Financial centers in Europe such as Amsterdam and asset price movement were independent(Craven and Islam ,2008).Similar Observation has been shared by Rahman (2010) in the case of Dhaka Stock Exchange (DSE) in which painful memories of 1996 bubble is linked with the recent-scenario of the highly inflated asset prices in early 2010 that is being termed as bubble because DSE has been risen by nearly 125 percent over the period from March 2009 to February 2010.Many times the asset price bubbles might result in economic downfall (Lewis et al 2010).

While empirical tests of return-volatility behavior and Market overvaluation are plentiful for developed markets, the focus on developing and emerging markets has only begun in recent years. The interest in these emerging markets has arisen from the increased globalization and integration of the world economy in general and that of financial markets in particular. The globalization and integration of these markets has created enormous opportunities for domestic and international investors to diversify their portfolios across the globe. As a result, rigorous empirical studies examining the efficiency and other characteristics of these markets would be of great benefit to investors and policy makers at home and abroad.

This study is important for a number of reasons. First, to the best of our knowledge, this is the first study of this kind for the Bangladesh market. Second, it utilizes the share prices of 17 actively companies being operated in Bangladesh. Third, the results of this study will be of interest to academics, policy makers and investors both at home and abroad. Finally, it may also be useful for international organizations (such as the World Bank) and foreign governments who are interested in the development of markets in emerging countries.

\section{Literature ReView}

The United States experienced the Nasdaq bubble in the late 1990s. The fluctuations beliefs generated by overconfidence among Bangladesh investors led to larger speculative component in stock prices, and the technical bubble of the U.S. market was identified as the result of "exuberance" (Shiller, 2000; Chen, Hong, and Stein, 2002). Given that markets in the advanced economies seemed to be more susceptible to speculative bubbles and crashes, and many emerging markets also display similar evidence, it seems reasonable that no one should look forward to these phenomena disappearing from the Bangladesh markets (Ahmed et al., 2006).

There are many literatures investigating market valuations. Traditionally, stock valuation literature in accounting focuses on the fundamental value measures that address simultaneous prices and returns. Prior researches in the accounting literature such as Abarbanell and Bernard (1995) investigated the empirical properties of the residualincome formula to explain cross-sectional prices. Empirical studies by Frankel and Lee (1998) show that better pricing fit than the traditional dividend discount model as well as better predictive power than financial ratios analysis can be realized by the multi-stage residual income model. For example, Dong, Hirshleifer, and Teoh (2007) misevaluation as the deviation of market price from the fundamental value. They believe intrinsic value reveals a discounted value of analyst forecasts of future earnings that reflects growth prospects and opportunities. Thus, normalizing market price by intrinsic value which sorts out the extraneous effects of the firm's growth provides a purified 
measure of misevaluation. Their measure of market misevaluation minimizes the confounding of misevaluation effects and growth opportunities existing in many market and investment studies. Their findings indicate that firms respond to overvaluation by investing more. Overall, the authors applied a forward-looking fundamental measure and obtained a general measure of market misevaluation which sorts out growth effects.

The stock valuation literature in finance focuses on the ability of the fundamental measures to forecast future returns. For example, Fama and French (1988, 1989), and Campbell and Shiller (1988) examined relationship between market multiples, such as book-to-market ratio or dividend yield (dividend/price) and subsequent market returns. The authors emphasized on forecasting returns by simple valuation measures predictability of market returns.

While empirical tests of return-volatility behavior and Market overvaluation are plentiful for developed markets, the focus on developing and emerging markets has only begun in recent years. The interest in these emerging markets has arisen from the increased globalization and integration of the world economy in general and that of financial markets in particular. The globalization and integration of these markets has created enormous opportunities for domestic and international investors to diversify their portfolios across the globe. As a result, rigorous empirical studies examining the efficiency and other characteristics of these markets would be of great benefit to investors and policy makers at home and abroad.

Glassman and Hassett (1999) questioned the reason why the stock prices kept keep increasing when the market was thought to be fully valued or on the verge of a crash. The authors believed the incredible returns that stocks produced came from recognizing that stocks had been far riskier than bonds and as a result generates more returns. Glassman and Hassett (1999) think that stocks are terrific investments and investors are gradually shrinking the risk premium toward where it should be. They believed that investors are bidding up the prices of stocks because they are catching on to the true riskiness of stocks and hoping to have a higher return to compensate for that risk. Their anticipation of the Dow Jones Industrial Average to end up at 36,000 was considered extremely dangerous because people would get irrationally exuberant when they see the news and jump into the market without proper preparation.

Shiller (2000) claimed that there was a bubble in the U.S. market, mostly because of psychological factors or "exuberances" which are frequently used to illustrate a heightened state of speculative fervour. Shiller summarized the evidence against rationality of the market. Most of the evidence engages in the predictability of returns. For instance, subsequent ten-year returns are likely to be lower when stock prices are high relative to earnings. Shiller also argued that there are obvious pricing errors due to noise in stock prices since actual stock prices are more volatile than the present discounted value of actual dividends. In line with Shiller (2000), other researchers also discussed how price movements are led by social processes in a nonstationary environment or irrational market and that individuals value other person's opinion in assessing probabilities. For example Chen, Hong, and Stein (2002) analysed the overvaluation generated by beliefs. The authors conclude that the market overvaluation was caused by the investors' overconfidence.

Campbell and Shiller (2001) showed that stock prices are probably overvalued based on the dividend-price and price-smoothed-earnings ratios. According to the authors, the extreme valuation ratios outside historical range over the late 1990s poses a challenge to the traditional opinion that equity prices resemble a sign of rational expectations and that they substantially motivated by mean reversion. However, Campbell and Shiller disagreed that the traditional valuation levels and argued that their findings showed a poor long-term market outlook. In another study regarding bangaldesh market it is found that there is a general tendency among investors to hold onto their shares till the record date so that they get entitled for dividend, and then sells it off after the record date. This results in an increase in share supply which might result in price decrease (Zaman, 2011). Chowdhury \& Chowdhury (2010) gathered secondary data of publicly listed companies, traded in Dhaka Stock Exchange (DSE) and Chittagong Stock Exchange (CSE), to see the relationship between capital structure and firm value in Bangladesh. It was observed that by changing its current ratio, operating leverage, EPS, dividend payout ratio or share capital, a firm may increase its value in the market.Chowudhury \& Abdullah (2011) opines that lack of market regulation, lack of supply of good shares, presence of syndicate, lack of financial knowledge helped the market index jumped over 8000 point dusring December 2011. From the above review of literature it can be said that the research work carried out so far by various eminent scholars, though extensive, has not yet brought in a common conclusion in relation to market bubble. Moreover, very insignificant amount of work has been done in Bangladesh context and the few studies conducted have been largely inconclusive. This study tries to fulfill the gap of explaining stock market pardox whether the stock is really overvalued or undervalued with empirical evidence.

\section{Methodology}

The main objective of this paper is to analyze whether Market of Bangladesh is overvalued. There are a variety of ways to calculate whether the market is overvalued. The data for this study has collected from different companies listed in the DSC 20 list. To compare the Real price with the projected price of the companies we have considered the Earning per share model, Cash Flow per share model and Sale per share model. The calculations have been done on the basis on the secondary data. There are several stock valuation models. The most popular and simplest technique for stock valuation is comparing the market's $\mathrm{P} / \mathrm{E}$ (price earnings ratio), $\mathrm{P} / \mathrm{CF}$ ratio and $\mathrm{P} / \mathrm{S}$ 
ratio to historical averages. (EPS, CFPS, SPS).

For the analysis purpose we have resorted to secondary data. The sample includes stock prices of actively traded 17 companies of Bangladesh in both DSE and CSE. Stock prices of each company are taken for 2006, 2007, 2008, 2009, and 2010. Among the Banks include (Dhaka Bank,Islami Bank, National Bank Limited, Prime Bank, Southeast Bank), Leasing Company (Uttara Finance),Pharmaceuticals include(Square Pharma) and other companies include(Aci,Amcl Pran,Apex tannery Ltd,Bata Shoe,BatBc ,Bd Lamps,Boc,GQ Ball Pen, Megnament and Monnocera,SingerBd).lastly forecasted share price is compared with market price of the November 27th ,2011 share price (www.dsebd.org).

Long horizon historical researches on equity prices examined how firm and investor performances have changed over time and across economic conditions in an attempt to better understand what factors drive value. In order to understand how investors value financial assets, Foerster and Sapp (2006) examined stock valuation using fundamental valuation methods and compared it to the actual price for equity over a long period of time. In the process of evaluating the level of pricing errors which is defined as the differences between the actual price levels for the index and expected prices, they find that the mispricing level is normally connected with changes in economic and price-related factors. Relationship between these factors and the short-term fluctuations in actual prices around expected price indicates that investors' expectations indeed play a significant role in pricing.

\section{FINDINGS}

At first we analyzed each of the 17 companies individually based on the P-E ratio, P-CFPS ratio and P-SPS ratio. This analysis shows stock price overvaluation for majority of the companies while undervaluation for some other companies. Then to have an understanding of the overall Market direction, combined the three types of valuation ratios on the year basis (Table 1 ).

We began by examining behavior of the data over time. As indicated by Table 1, in which average yearly ratios are presented for the last five years. Over the 5-year periods, the three types of ratios show increasing trend. One reason for this increasing trend, maybe, that with their increasing emphasis on growth, these firms have increased earnings retention ratio, reducing dividend yield. At the same time their initial success and market's expectations that they would continue to succeed in generating high growth rates pushed price earnings ratio to historically high levels. This is reasonable because investors have been willing to accept these tendencies because of the increased availability of means of risk reduction.

Another reason may be that a sudden influx of funds and a surge in retail investors are pushing the DSE index forward without regard to fundamentals. The Index which was at 2941 in August in 2009 has crossed 5800 points in February 2010 (see figure 1), or a growth of 98 percent. This surge is certainly not normal and cannot be explained by fundemetals (Rahman 2010; Mansur and Hoque 2010). Market capitalization (total number of shares times the average market price of shares) in August 2009 was Tk 1307 billion and February 2010, it has risen to taka 2366 billion, recording an increase of 81 percent within the 5-month periods. Just to put it in proper perspective, the market capitalization was only TK97 billion in Dec 2003 before the beginning of the current Bull-Run. The daily average turnover showed a similar trend, increasing from Tk.14 billion in Dec 2003 to Tk 12 billion in Jan 2010 and further to Tk 14 billion in the first half of February. In 2009 Daily turnover did not fell below Tk 10 billion Which was a miniscule Tk.26 billion in 2004 (Mansur and Haque,2010).

While the supply of stocks is almost unaffected, accepts for the launching of Grameen Phone IPO in November 2009 , pressures in stock prices are exerted from the demand side. Among many factors, huge numbers of new investors with fresh funds primarily responsible for this price pressure. During 2009 period on an average of 12000 new investors are joining the market everyday (Mansur and Hoque, 2010).Huge amount of fresh money are channeled into market through these new accounts, undoubtedly pumping the market balloon to grow bigger almost every day. If the average account size is Tk $.1 \mathrm{mil}-$ lion, everyday Tk 1.2 million are being poured into the market, mostly by the retail investors (Rahman, 2010).

Table: 1 shows an increasing trend in the three types of ratios being analyzed. From that particular data drawing any conclusion whether the market is overvalued or not is difficult and in many cases may result in many contradictions. For the purpose of more accuracy and authentication, I have analyzed numerous factors such as Market Capitalization, Number of $\mathrm{BO}$ account holders in the DSE, which is the largest market in Bangladesh, in corresponding periods. The particular data showed erratic increase in Market Capitalization and BO account holders in corresponding periods (2006-2010). We could observe that the stocks are mostly overvalued and when undervalued the prices are too low. (Look at tables 2, 3 \& 4) The reasons might be:

1. Stocks have recovered from recession situation but the Bangladeshi economy hasn't.

2. Price of the stocks may have increased unexpectedly.

3. The experts' predictions and the current Market situation are not similar.

4. People are more interested investing in the purchasing stocks, so more money is finally flowing into stocks.

5. The companies might be using misleading information to value their stocks.

\section{Conclusion}

The Dhaka Stock Exchange limited has been generally bearish, excepts speculative run-up for six during the 
later part of 1996, and the companies do not hold annual general meetings (AGM) as stipulated in company guidelines, nor do they declare dividends or invest the retained earnings in value maximizing investments. The primary objective of the paper was to analyze week form efficiency of DSE all share index and DSE Top 20 index and Day Wise index (Sunday, Monday, Tuesday, Wednesday and Thursday) and individual stock prices of the proxy companies (23 companies operating in the rapidly growing Pharmaceuticals industry). The result presented in the study shows that the hypothesis of the randomness of the stock returns are rejected for stock price index changes at all frequencies using Augmented Dickey-Fuller test. Basic assumptions of Efficient Market Hypothesis are violated for Dhaka Stock Exchange that means the DSE market is not efficient even in week form. The rejection of null hypothesis of random walk can be interpreted by the mean reverting tendency of market prices. The postderegulation stock markets of South Asia appear in general to be efficient except in the case of Bangladesh for which the results are mixed. (Cooray and Wickramasighe, 2007)

The reason for the market inefficiency is also the poor institutional infrastructure, weak regulatory framework, Lack of supervision, and a lack of accountability, poor corporate governance, slow development of the market infrastructure, and low level of capacity of major market players, and lack of transparency of market transactions. The processing of informationin Bangladesh is rather weak, and may result from the persistent large number of non-actively traded shares, and the limited role of mutual funds professionally managed investment and broker houses. As an institutional policy to improve the capital market, the timely disclosure and dissemination of information to the shareholders and investors on the performance of listed companies should be emphasized. Implication of the rejection of weak form efficiency investors is that they cannot adopt a 'fair return for risk' strategy, by holding a well-diversified portfolio while analysts and institutional investors is a well known fact in the emerging markets like Bangladesh. In south East Asia only Srilanka stock market was performing better than the Bangaldesh market last year. If we look at the in light of Southeast Asia other countries Sri Lanka, Pakistan as well as India has good gervernanace compare to Bangaldesh.

\section{REFERENCES}

[1] Abarbanell J., and Bernard V., 1995), "Is the U.S. Market Myopic?" University of Michigan Working Paper.

[2] Ahmed E., Li H., Rosser J. B., and Eastern Jr., 2006) “Nonlinear Bubbles in Chinese Markets in the 1990" Economic Journal, Vol. 32, No. 1.

[3] Allen and Gale Asset price bubbles and market interlink ages-Working paper, Wharton school, university of Pennsylvania.usa. 2002.

[4] Ashraf and Rodriguez, Estimated Long Memory Fractional Parameter and impacts on the volatility of the financial Markets: some specualtions'North south Business review, 1(1) 1-16, 2006.
[5] Campbell, John Y., and Robert J. Shiller (1998, 2001), "Valuation Ratios and the Long-Run Market Outlook: An Update." NBER Working Paper 8221, April 2001.

[6] Chapman, Evedence for a speculative Bubble in the clean energy Sector: an event study, Master thesis, Department of Economics, University of Shaffield, UK., 2007.

[7] Chen J., Hong H., and Stein, J. C., "Breadth of Ownership and Stock Returns", Journal of Financial Economics, Vol. 66, pp. 171-205. 2002.

[8] Chowdhury, A. \& Chowdhury, S. P. (2010). Impact of capital structure on firm's value: Evidence from Bangladesh. Business and economic horizon, 3 (3), 111-122.

[9] Chowudhury, R.A \& Abdullah M.N. (2011) “Overheated stock market: remedial measures for soft landing"; Journal of the institute of cost \& management accountants of Bangladesh, volume xxxix, and number 5, page- 28 .

[10] Cooray, AV and Wickramasighe, G, the Efficiency of Emerging Stock Markets: Empirical Evidence from the South Asian Region. Journal of Developing Areas, 41(1), 2007, 171-183.

[11] Craven and Islam, (2008) A Model for Market Returns: NonGaussianFluctuations and Financial Factors' Review of quantitative Finance and accounting, 30,355-370.

[12] Dong M, Hirshleifer, D., and Teoh, S. H. (2007), “Market Misvaluation and Corporate Investment", Unpublished MPRA Paper, at http://mpra.ub.uni-muenchen.de/3109/

[13] Fama E. and French K., (1988), “Dividend Yields and Expected Stock Returns", Journal of Financial Economics, Vol. 22, pp. 3-25.

[14] Fama E., and French K., (1989), "Business conditions and expected returns on stocks and. Bonds", Journal of Financial Economics 25, pp. 23-49.

[15] Frankel R. and Lee C. M. C., (1998), “Accounting Valuation, Market Expectation and Cross-Sectional Stock Returns", the Journal of Accounting and Economics, Volume 25, pp. 283-319.

[16] Foerster S. R. and Sapp S., (2006), “Dividends and Stock Valuation: A Study from the Nineteenth to the Twenty-First Century", retrievable at SSRN: http:// ssrn.com/abstract=890445.

[17] Ghazi and Khoda, (2010) An Empirical Examination of Random Walk Hypothesis for Dhaka Stock Exchange: Evidence from Pharmaceutical Sector of Bangladesh International Research Journal of Finance and EconomicsISSN 1450-2887 Issue 33 (2009) @ Euro Journals Publishing, Inc. 2009http://www.eurojournals.com/finance.htm

[18] Glassman, James, and Kevin Hassett (1999) Dow 36000: The New Strategy for Profiting from the Coming Rise in the Market. New York: Times Business, 1999.

[19] Zaman, S. (2011). Is Dividend Policy An Important Determinant Of Market Performance: Focus On Private Banks Of Bangladesh? World Review of Business Research, 1(4), 135-144.

[20] Rahman (2010) Bubble is DSE, Worg Press, and Dhaka.

[21] Kindleberg Bubbles in J.Eatwell, M.Milgate and p.Newman (Eds), The new Palgrave: A Dictionary of Economics, Vol.1.Stockholm press, Newyork. 1987.

[22] Knight, A Bubble in the Mighty Mississippi: An application of a general Model of speculative bubbles of 1716-1720.Major themes in Economics spring. 2002.

[23] Lewis et al, Was the 2008 financial crisis caused a lack of corporate ethics? Global Journal of business research, 4(20), 77-84, 2010

[24] Mansur and Hoque, 2010) Market: A ticking Bomb, the Financial Express, February, 19.

[25] Shiller, Robert J., exuberance (Princeton, N.J.: Princeton University Press, 2000. 
TABLE: 1 AVERAGE YEARLY RATIO

$\begin{array}{cccc}\text { YEAR } & P \backslash E P S & P \backslash C F P S & P \backslash S P S \\ 2006 & 12.09 & 14.61 & 3.59 \\ 2007 & 13.15 & 29.80 & 6.01 \\ 2008 & 29.93 & 56.91 & 70.95 \\ 2009 & 47.19 & 55.95 & 7.61 \\ 2010 & 34.84 & 49.09 & 10.21\end{array}$

Figure: 1 TREND IN MARKet CAPITALIZATION IN DSE from JanUARY 12004 TO JUNE24, 2010

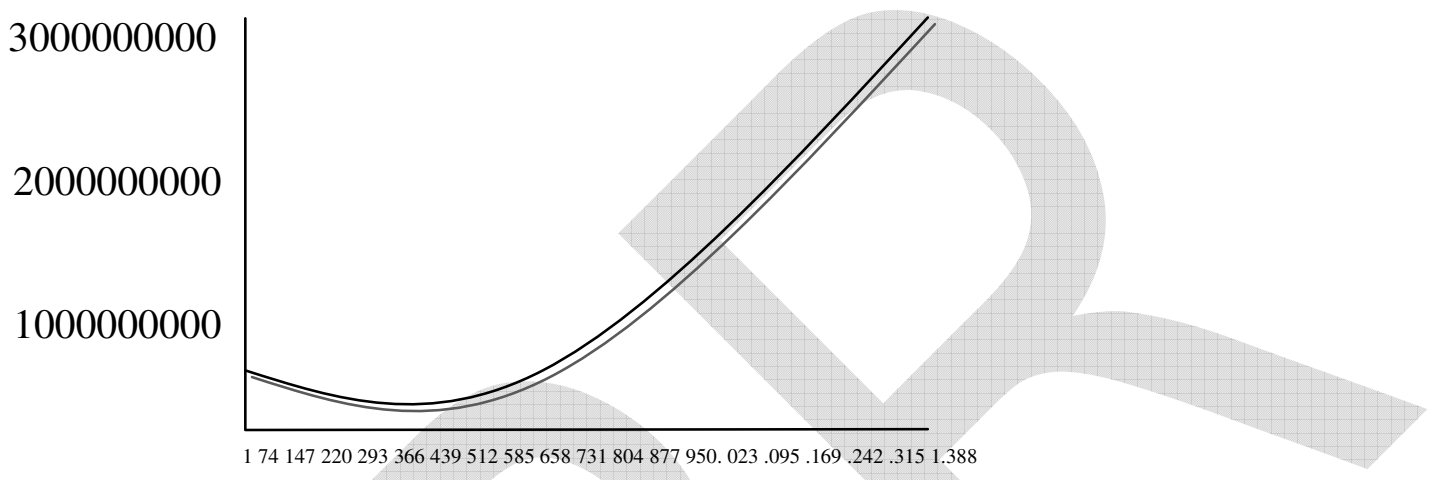

TABLE: 2 ExpeCted Stock Price of the Companies under different Ratios

\begin{tabular}{|l|l|l|l|}
\hline Company Names & $\mathrm{p} / \mathrm{eps}$ & $\mathrm{p} / \mathrm{cfps}$ & $\mathrm{p} \backslash \mathrm{sps}$ \\
\hline ACI & $\mathbf{3 7 2 . 8 9 9 8}$ & $\mathbf{6 6 . 9 6 7 0 4}$ & $\mathbf{4 8 5 . 3 5 9 4}$ \\
\hline AMSL PRAN & 1276.0954 & 2354.5173 & 3267.6125 \\
\hline APEX & $\mathbf{1 2 9 4 . 9 0 8 9 3}$ & $\mathbf{1 2 9 4 . 9 0 8 9 3}$ & $\mathbf{3 5 3 . 6 2}$ \\
\hline BATA SHOE & 500.120491 & 470.5059584 & 459.615625 \\
\hline BATBC & 953.28991 & 711.212236 & 766.849378 \\
\hline BD LAMPS & 1852.276 & 2027.913946 & 1902.777041 \\
\hline DHAKA BANK & $\mathbf{4 9 . 2 5 4 6 2 8 8}$ & $\mathbf{1 0 3 . 4 9 1 0 5}$ & 291.5066436 \\
\hline GQ BALL PEN & 441.9598 & 159.3997631 & 171.2615506 \\
\hline ISLAMI BANK & 970.38 & $\mathbf{7 2 1 . 0 5}$ & 1695.32 \\
\hline $\begin{array}{l}\text { MEGNA CEMENT } \\
\text { MONNO CERAMIC }\end{array}$ & $\mathbf{5 2 6 . 8 3 3 0 9 5 4}$ & $\mathbf{6 7 2 . 7 4 9 6 3}$ & 361.7748811 \\
\hline NBL & 1437.146677 & 4283.739602 & 145.4728884 \\
\hline PRIMEBANK & $\mathbf{5 2 . 5 9 8 9 4 8 4}$ & $\mathbf{5 5 2 . 4 2 6 3 3 5 4}$ & $\mathbf{3 9 6 . 3 0 5 8 9 5 5}$ \\
\hline SINGERBD & 8446.972 & 6006.666655 & 6070.443419 \\
\hline SOUTHEAST BANK & 472.7394 & 311.1055098 & 543.6509669 \\
\hline SQUARE PHARMA & 4550.19 & 4116.67 & 4164.57 \\
\hline UTTARA FINANCE & $\mathbf{1 6 9 . 0 9 5}$ & 562.7131 & 46.8459 \\
\hline BOC & 798.3657 & 646.295265 & 198.9489316 \\
\hline
\end{tabular}


table -3 Calculations Of P-Eratio, P-Cfpsratio and P-Sps Ratio on Year Basis

\begin{tabular}{|c|c|c|c|c|c|c|c|c|c|c|c|c|c|c|c|}
\hline \multirow[b]{2}{*}{$\begin{array}{l}\text { COMPANYNAMES } \\
\text { ACI }\end{array}$} & \multicolumn{3}{|c|}{2006} & \multicolumn{3}{|c|}{2007} & \multicolumn{3}{|c|}{2008} & \multicolumn{3}{|c|}{2009} & \multicolumn{3}{|c|}{2010} \\
\hline & $\begin{array}{l}\text { ple } \\
7.4\end{array}$ & $\begin{array}{l}\text { plef } \\
104\end{array}$ & $\begin{array}{l}\text { p } / \text { s } \\
.2685\end{array}$ & $\begin{array}{l}\text { ple } \\
95\end{array}$ & $\begin{array}{l}\text { plc } \\
298\end{array}$ & pls & $\begin{array}{l}\text { ple } \\
7.8\end{array}$ & $\begin{array}{l}\text { ple } \\
38.49\end{array}$ & $\begin{array}{l}\text { pls } \\
0.70\end{array}$ & $\begin{array}{l}\text { ple } \\
8.8\end{array}$ & $\begin{array}{l}\text { ple } \\
-14.40\end{array}$ & $\begin{array}{l}\text { pls } \\
0.73\end{array}$ & $\begin{array}{l}\text { ple } \\
122\end{array}$ & $\begin{array}{l}\text { ple } \\
50.00\end{array}$ & $\begin{array}{l}\text { pls } \\
0.52\end{array}$ \\
\hline AMSLPRAN & 10.67 & 5.77 & 7.58 & 10.92 & 5.01 & 1105 & 2533 & 12.46 & 31.01 & 27.32 & 35.82 & 30.39 & 3146 & 12.47 & 1247 \\
\hline$A P E X$ & 891 & 1238 & 0.17 & 17.03 & 2223 & 0.17 & 38.25 & 39870 & 0.36 & 1234 & 6.62 & 113 & 15.84 & 51.62 & 1.31 \\
\hline BATA SHOE & 600 & 5.12 & 0.43 & 942 & 10.11 & 0.77 & 9.76 & 11.86 & 0.95 & 16.08 & 17.20 & 145 & 1646 & 17.74 & 1.49 \\
\hline BATBC & 13.95 & 83 & 15.6 & 1115 & 9.7 & 112 & 7.25 & 7.2 & 7.3 & 11.87 & 11.1 & 115 & 1493 & 153 & 19.6 \\
\hline BD LAMPS & 10.26 & 153 & 1.10 & 15.32 & 6.10 & 154 & 14.30 & 7.17 & 147 & 22.77 & 555.35 & 217 & 3050 & 19799 & 3.03 \\
\hline DHAKABANK & 10.31 & 324 & 1.76 & 15.52 & 299 & 286 & 831 & 287 & 179 & 13.4 & 0.86 & 030 & 163 & 1.85 & 0.48 \\
\hline GQBALL PEN & 23.96 & 128 & 1.24 & 10.03 & 9.37 & 297 & 165.42 & 19.97 & 257 & 23.33 & 25.82 & 461 & 4281 & 19.87 & 5.61 \\
\hline ISLAMI BANK & 7.59 & 7.45 & 0.31 & 22.08 & 2208 & 8.77 & 14.03 & 14.03 & 5.08 & 12.87 & 12.87 & 528 & 17.86 & 5522 & 7.78 \\
\hline MEGNA CEMENT & 35.65 & 1534 & 2.79 & 0 & 0 & 0 & 84.16 & 45.64 & 405 & 54309 & 47.46 & 492 & 188.82 & 24.89 & 5.73 \\
\hline $\mathrm{NBL}$ & 12.07 & 4997 & 3.65 & 22.6 & 124 & 3.28 & 19.03 & 864 & 1102 & 8.88 & 7.32 & 759 & 1232 & 21.3 & 15 \\
\hline PRDE B.ANK & 9 & 271 & 6.31 & 15.02 & 3.54 & 1104 & 1229 & 9.81 & 7.79 & 10.69 & 0.36 & 124 & 1849 & 0.76 & 1.74 \\
\hline SINGERBD & & & & & & & 29.06 & 104 & 104 & 24.42 & 1.37 & 147 & 8214 & 596 & 6.00 \\
\hline SOUTHEAST B ANK & 600 & 642 & 3.13 & 942 & 7.16 & 3.02 & 9.76 & 4.33 & 257 & 16.08 & 12.81 & 5.14 & 1646 & 21.54 & 5.36 \\
\hline SQUARE PH.ARMLA & 29.46 & 90.37 & 1116 & 28.33 & 26399 & 1142 & 44.88 & 223.75 & 13.50 & 23.43 & 15089 & 10.67 & 25.88 & 20879 & 11.02 \\
\hline UTTARAFINANCE & 5.35 & 535 & 535 & 848 & 5.72 & 8.48 & 8.14 & 70.58 & 8.14 & 1697 & 14.13 & 14.02 & 3379 & 30.09 & 4292 \\
\hline $\mathrm{BOC}$ & 900 & 77.13 & 0.26 & 19.00 & 123.25 & 25.04 & 11.00 & 90.81 & 15.82 & 1200 & 65.53 & 26.69 & 1600 & 99.07 & 33.42 \\
\hline TOTAL & 205.58 & 24845 & 61.12 & 223.62 & 506.67 & 10214 & 508.74 & 967.38 & 1206.17 & 80234 & 95114 & 12934 & 59226 & 83449 & 173.52 \\
\hline
\end{tabular}

TABLE: 4

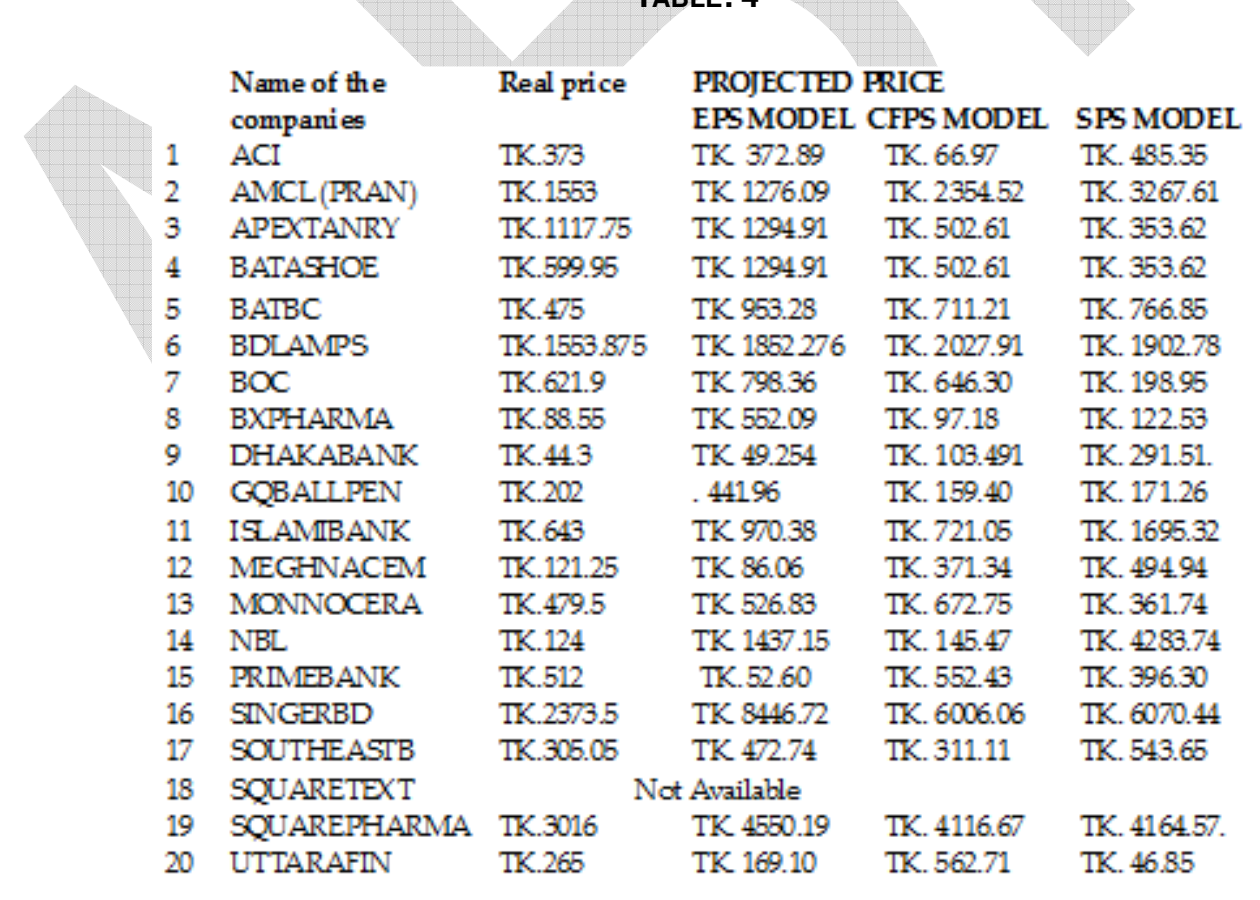

